\title{
Cytokeratin intermediate filament expression in benign and malignant breast disease
}

\author{
M Heatley, P Maxwell, C Whiteside, P Toner
}

\begin{abstract}
Aim-To carry out a comprehensive study of cytokeratin expression in benign and malignant breast epithelium and breast myoepithelial cells; to examine changes in the cytokeratin profile in malignant and benign epithelium and in carcinomas of increasing histological grade.

Methods-Frozen sections from fibroadenomas (19 cases), fibrocystic disease (19 cases), and infiltrating ductal (68 cases), lobular (seven cases), and mucinous carcinomas (three cases) were examined using a panel of monoclonal antibodies.
\end{abstract}

Results-The luminal epithelium in all fibroadenomas and all cases of fibrocystic disease, as well as tumour cells in most carcinomas, reacted with the specific antibodies to cytokeratins $7,8,18$, and 19 and to antibodies which included these cytokeratins in their specificities (Cam 5•2, AE1, AE3, RCK102, and LP34). In a few ductal carcinomas none of the tumour cells reacted for cytokeratins 7,8 , or 18. Three ductal carcinomas expressed cytokeratin 14. Only occasional cases expressed cytokeratins $3,4,10$, and 13 . Antibodies which included cytokeratins 5 and 14 in their specificities detected myoepithelial cells less efficiently than antiactin antibodies.

Conclusion-The cytokeratin profiles in the luminal epithelium in benign breast disease and in tumour cells in most carcinomas are similar in most cases. Some carcinomas, however, are negative for cytokeratins 7,8 , or 18 . This may provide a means of predicting the biological behaviour of a histologically borderline lesion.

(F Clin Pathol 1995;48:26-32)

Keywords: Breast, cytoskeletal proteins, cytokeratins.

Department of Pathology, The Royal Group of Hospitals Trust, Grosvenor Road Belfast BT12 6BI $M$ Heatley P Maxwell C Whiteside $P$ Toner Correspondence to: Mr P Maxwell.

Accepted for publication 1 July 1994
The cytoskeleton of eukaryotic cells contains intermediate filaments, which measure 7-11 $\mathrm{nm}$ in diameter as well as microtubules and microfilaments. ${ }^{1}$ Depending on their relative molecular mass and protein structure, cytoplasmic intermediate filament proteins have been categorised into five classes. The twenty cytokeratin intermediate filament proteins are typically expressed in epithelial cells and in carcinomas. ${ }^{2-5}$ Between two and 10 cytokeratins are typically expressed by epithelial cells depending on the cell type, growth environment in the tissue, embryonic development, state of tissue development, and the presence of disease. ${ }^{6}$

Whilst carcinomas usually express the cytokeratin profile of their tissue of origin, ${ }^{16}$ exceptions may occur. Tumours may either begin to express a novel cytokeratin or, alternatively, may cease to express cytokeratins which are normally present in their tissue of origin. ${ }^{7}$ Furthermore, changes in the profile of cytokeratin expression have been found with increasing tumour grade. These changes may also be caused by alterations in the epitope configuration of some cytokeratins. ${ }^{8-10}$

This study was carried out to determine whether cytokeratin expression can be used to distinguish malignant tumours of the breast from benign conditions. The value of cytokeratin expression in predicting patient prognosis was also studied, by seeking an association between the expression of different cytokeratins and tumour grade, in ductal carcinomas. The expression of cytokeratins in breast myoepithelium and in a group of unusual tumours is also described.

As routine tissue processing with formalin based fixatives results in denaturing of antigens, this study was performed on frozen section material. Although resulting in some loss in the quality of morphology, the use of frozen sections provides the optimal means for preserving immunoreactivity. Alcohol fixation and freeze drying followed by embedding the material in paraffin wax result in only mild antigenetic distortion and give good morphology. ${ }^{3112}$

\section{Methods}

Fresh specimens of breast tissue, including those from lumpectomies and mastectomies for malignant conditions and local excisions for benign breast disease, were transported on ice from the operating theatre to the histopathology laboratory. In most cases a previous fine needle aspiration biopsy had been performed and a diagnosis of benign or malignant breast disease had been established. On arrival in the laboratory, the resection margins were marked with indian ink. Impalpable lesions were fixed in $10 \%$ unbuffered formol saline before sectioning and were excluded from the study. All other specimens were sectioned at $1 \mathrm{~cm}$ intervals.

A small portion of tissue measuring $1 \times 1$ $\times 0.5 \mathrm{~cm}$ was excised and immediately 
Table 1 Specificities of antibodies used

\begin{tabular}{|c|c|c|c|}
\hline Antibody & Specificity & Supplier & $\begin{array}{l}\text { Dilution on } \\
\text { cryostat sections }\end{array}$ \\
\hline RCK105 & Cytokeratin 7 & \multirow{5}{*}{$\begin{array}{l}\text { Euro- } \\
\text { Diagnostica bv } \\
\text { Dakopatts } \\
\text { ICN } \\
\text { ICN } \\
\text { Beckton } \\
\text { Dickenson } \\
\text { Cymbus }\end{array}$} & 1 in 20 \\
\hline $\begin{array}{l}\text { BA17 } \\
\text { M20 }\end{array}$ & $\begin{array}{l}\text { Cytokeratin } 19 \\
\text { Cytokeratin } 8\end{array}$ & & $\begin{array}{l}1 \text { in } 10 \\
1 \text { in } 20\end{array}$ \\
\hline RGE53 & Cytokeratin 18 & & 1 in 20 \\
\hline Cam $5 \cdot 2$ & $\begin{array}{c}\text { Cytokeratins } \\
8,18,19\end{array}$ & & 1 in 10 \\
\hline Anticytokeratin 14 & $\begin{array}{l}\text { Specific antibody to } \\
\text { cytokeratin } 14\end{array}$ & & 1 in 10 \\
\hline RCK102 & $\begin{array}{l}\text { Cytokeratins } \\
5,8\end{array}$ & \multirow{2}{*}{$\begin{array}{l}\text { Euro- } \\
\text { Diagnostica bv } \\
\text { ICN }\end{array}$} & 1 in 20 \\
\hline $\mathrm{AE} 1$ & $\begin{array}{l}\text { Cytokeratins } \\
10,14,15,16,19\end{array}$ & & 1 in 50 \\
\hline AE3 & $\begin{array}{l}\text { Cytokeratins } \\
1-8\end{array}$ & ICN & 1 in 50 \\
\hline $\mathrm{AE} 2$ & $\begin{array}{l}\text { Cytokeratins } \\
1,2,10,11\end{array}$ & ICN & 1 in 50 \\
\hline LP34 & $\begin{array}{l}\text { Cytokeratins } \\
6,18\end{array}$ & Dakopatts & 1 in 10 \\
\hline $\begin{array}{l}\text { AE5 } \\
\text { AE8 }\end{array}$ & $\begin{array}{l}\text { Cytokeratin } 3 \\
\text { Cytokeratin } 13\end{array}$ & \multirow{3}{*}{$\begin{array}{l}\text { ICN } \\
\text { ICN } \\
\text { Euro- } \\
\text { Diagnostica bv } \\
\text { Euro- } \\
\text { Diagnostica bv }\end{array}$} & $\begin{array}{l}1 \text { in } 50 \\
1 \text { in } 50\end{array}$ \\
\hline RSKE60 & Cytokeratin 10 & & 1 in 20 \\
\hline $6 \mathrm{~B} 10$ & Cytokeratin 4 & & 1 in 20 \\
\hline
\end{tabular}

Table 2 Total number of cases studied in each group

\begin{tabular}{ll}
\hline Type of disease & No. of patients \\
\hline Infiltrating ductal carcinoma & 68 \\
Lobular carcinoma & 7 \\
Mucinous carcinoma & 3 \\
Phyllodes tumour (benign) & 2 \\
Phyllodes tumour (malignant) & 1 \\
Fibroadenoma & 19 \\
Fibrocystic disease & 19 \\
\hline
\end{tabular}

plunged into pre-cooled isopentane (Prolabo, Paris, France). Sections were cut at $5 \mu \mathrm{m}$ intervals on a Bright cryostat. Cytokeratins were detected on cryostat sections using monoclonal antibodies at the dilutions shown in table 1, using the indirect peroxidase method.

Following fixation, gross dissection of the specimen was completed the following morning, when representative blocks were taken for histological examination. The definitive diagnosis was made on $4 \mu \mathrm{m}$ paraffin sections stained with haematoxylin and eosin and the tumours typed as infiltrating ductal, lobular,

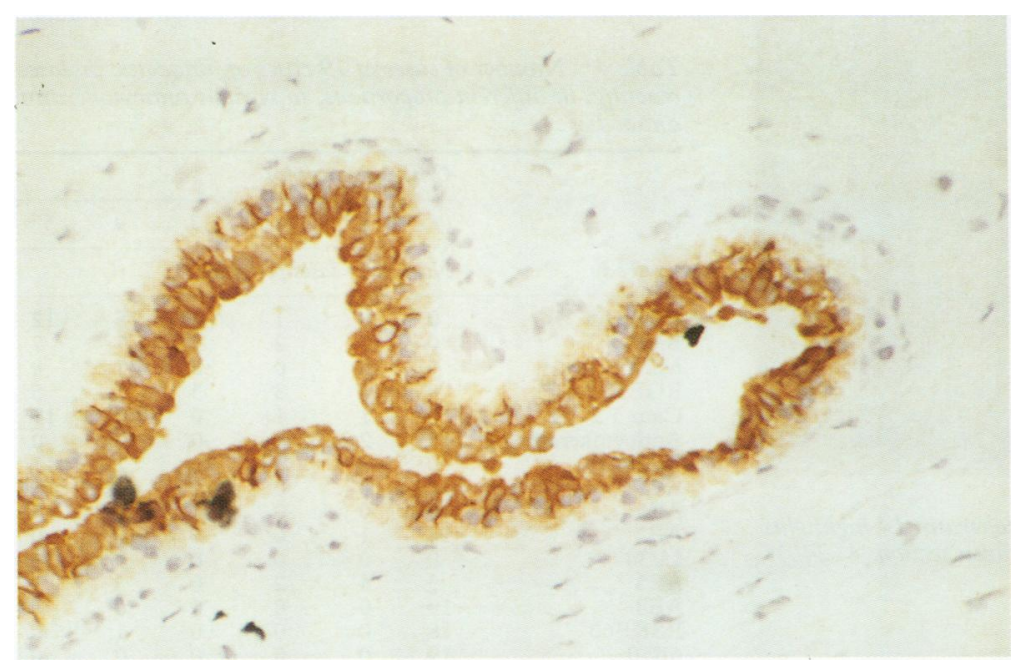

Figure 1 Staining of the luminal epithelium in this fibroadenoma is seen with an antibody specific to cytokeratin 8 . The myoepithelium does not react with this antibody (frozen section $\times 240$ ). or mucinous carcinomas. Ductal carcinomas were graded according to the system devised by Bloom and Richardson ${ }^{13}$ and modified by Elston et al. ${ }^{14}$ For statistical analysis, 12 cases of fibroadenosis, four of fibrocystic disease, one of sclerosing adenosis, one of duct ectasia, and one histologically normal breast were grouped together under the heading fibrocystic disease. The haematoxylin and eosin stained frozen sections in each of these cases were examined and compared with the paraffin sections to ensure that the appearances of the frozen sections were representative of those in the breast as a whole.

In each case slides were reviewed on a Leitz Laborlux $\mathrm{K}$ microscope. A positive reaction with each of the antibodies was noted when there was distinct brown staining in the epithelial cells in breast sections. The proportion of cells reacting with the antibody was estimated on a semiquantitative scale. Cases were graded between one and five, depending whether under $25,26-50,51-75,76-99$, or $100 \%$ of the epithelial or tumour cells reacted with the antibody under study. If no staining was present in the epithelium, the case was graded as zero.

The presence of a reaction in myoepithelial cells in cases of fibrocystic disease, fibroadenomas, and surrounding foci of ductal carcinoma in situ, adjacent to 22 of the invasive tumours, was noted and the proportion of these cells reacting with each antibody estimated. In keeping with the protocol for examining breast specimens described above no case of ductal carcinoma in situ was sampled without associated invasion.

The proportion of tumour cells reacting with each antibody in invasive ductal carcinomas was compared with the proportion of epithelial cells in the benign conditions to determine whether any difference was statistically significant. A comparison was also made between the proportion of cells reacting in fibroadenomas and in fibrocystic disease. Both of these comparisons were carried out using the Mann-Whitney U test. If either of the analyses resulted in a statistically significant difference, the proportion of cells reacting in ductal carcinomas was compared, firstly, with the proportion reacting in the fibroadenomas and, secondly, with the proportion in fibrocystic disease, using the Mann-Whitney $U$ test. This latter analysis was performed to determine which of the benign conditions resulted in the difference between the benign and malignant groups.

The proportions of cells reacting with antibodies in each of the three grades of infiltrating ductal carcinoma were also compared to determine whether cytokeratin expression changed with differences in tumour grade. This statistical analysis was performed using the Kruskal-Wallis test.

The reaction pattern of the various antibodies with the myoepithelial cells surrounding areas of in situ ductal carcinoma and the benign breast diseases were compared using the Mann-Whitney $U$ test. A p value of $<0.05$ was considered significant. 


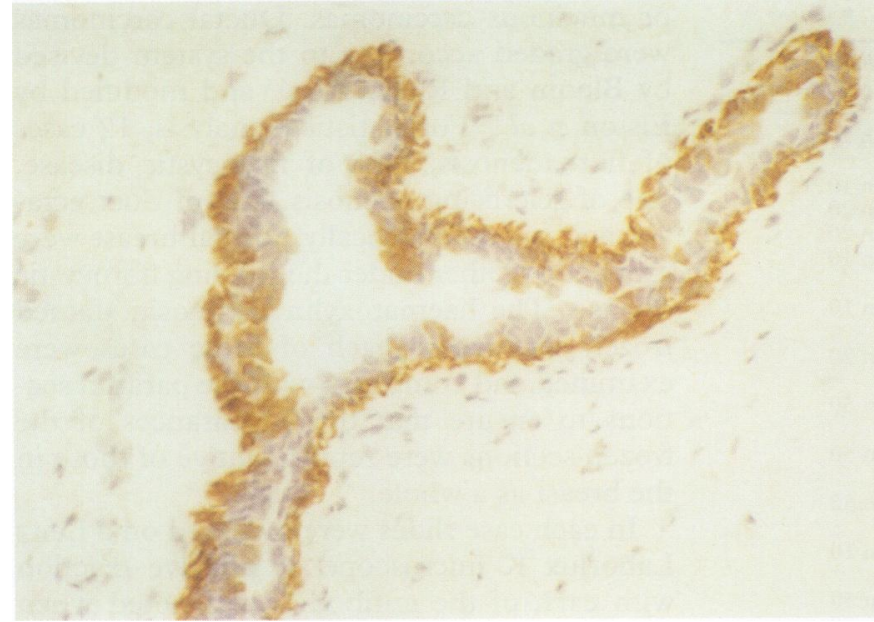

Figure 2 In a section adjacent to that in fig 1 complementary staining of myoepithelial cells is seen with the antibody to cytokeratin 14 . No reaction is evident in the luminal epithelium (frozen section $\times 240$ ).

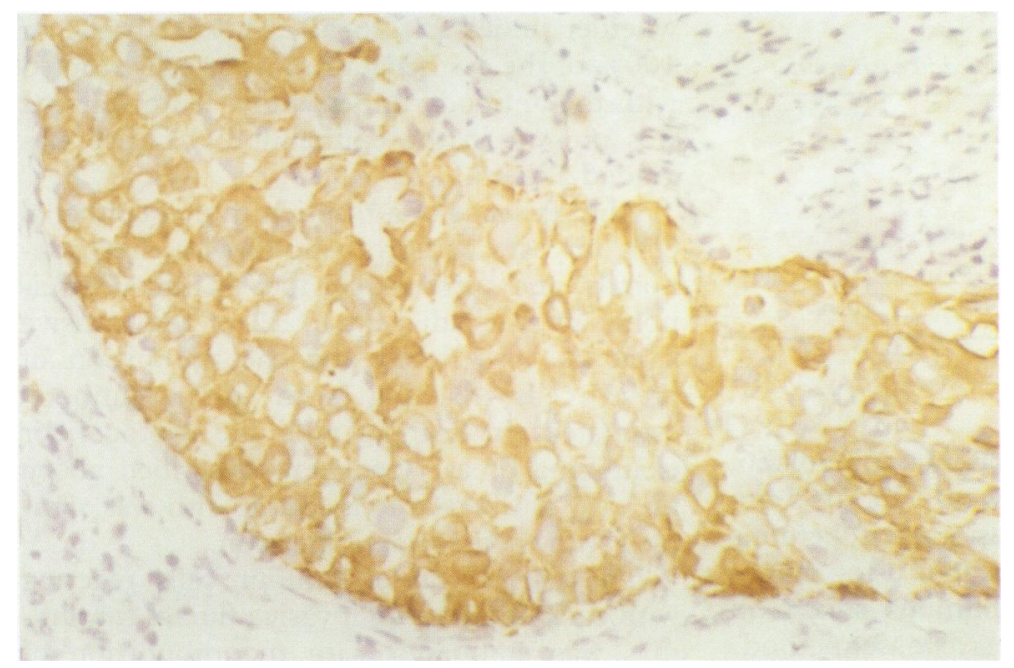

Figure 3 The antibody to cytokeratin 8 reacts with the luminal tumour cells in this focus of in situ ductal carcinoma (frozen section $\times 240$ ).

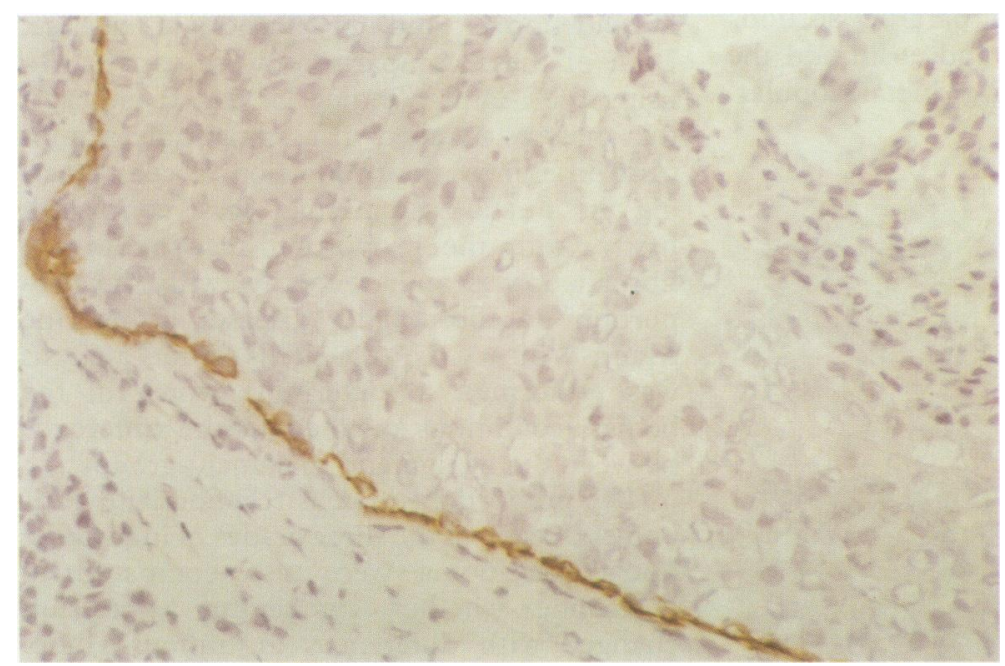

Figure 4 In a section adjacent to that in fig 3 the antibody to cytokeratin 14 highlights the myoepithelial cells surrounding the foci of in situ carcinoma (frozen section $\times 240$ ).

\section{Results}

Cytokeratins were detected in the luminal epithelium of the 19 fibroadenoma cases, the 19 cases of fibrocystic disease, the three phyl- lodes tumour cases, and in the tumour cells in the 68 cases infiltrating ductal, the seven cases of lobular, and the three cases of mucinous carcinoma (table 2 and figs 1-5).

The luminal epithelial cells in most cases of benign breast disease expressed cytokeratins $7,8,18$, and 19 and reacted with the antibodies which included these molecules in their spectrum of reactivity (RCK105, BA17, M20, RGE53, Cam 5.2, RCK102, AE1, AE3, and LP34). In some cases this staining was heterogeneous (tables 3 and 4). A similar pattern of reaction was seen in the tumour cells of the infiltrating ductal carcinomas, although a subgroup of tumours was identified in which one or more cytokeratins were absent from all of the cancer cells (table 5).

In cases of benign breast disease there was a statistically significant difference in the proportion of tumour cells and luminal epithelial cells which reacted with the antibodies to cytokeratins 7 and $19(\mathrm{p}=0.0044$ and $\mathrm{p}=$ 0.0032 , respectively; table 6 ). There were statistically significant differences in the proportions of tumour cells and luminal epithelial

Table 3 Number of cases of the 19 fibroadenoma cases reacting, in different proportions, to various anticytokeratin antibodies

\begin{tabular}{|c|c|c|c|c|c|c|}
\hline \multirow[b]{3}{*}{ Antibody } & \multicolumn{6}{|c|}{ Grade of reactivity } \\
\hline & 0 & 1 & 2 & 3 & 4 & 5 \\
\hline & \multicolumn{6}{|c|}{ Number of cases per grade } \\
\hline RCK105 & 0 & 0 & 0 & 0 & 2 & 17 \\
\hline BA17 & 1 & 0 & 0 & 2 & 8 & 8 \\
\hline $\mathrm{M} 20$ & 0 & 0 & 0 & 3 & 5 & 10 \\
\hline RGE53 & 0 & 0 & 1 & 6 & 9 & 1 \\
\hline Cam $5 \cdot 2$ & 0 & 0 & 1 & 1 & 1 & 16 \\
\hline Anticytokeratin 14 & 17 & 1 & 0 & 0 & 0 & 0 \\
\hline RCK102 & 0 & 1 & 0 & 0 & 7 & 11 \\
\hline $\mathrm{AE} 1$ & 0 & 1 & 0 & 0 & 4 & 14 \\
\hline AE3 & 1 & 0 & 0 & 1 & 6 & 11 \\
\hline $\mathrm{AE} 2$ & 17 & 2 & 0 & 0 & 0 & 0 \\
\hline LP34 & 1 & 0 & 1 & 0 & 6 & 11 \\
\hline AE5 & 5 & 1 & 2 & 2 & 2 & 6 \\
\hline AE8 & 18 & 1 & 0 & 0 & 0 & 0 \\
\hline RSKE60 & 17 & 0 & 0 & 1 & 0 & 0 \\
\hline $6 \mathrm{~B} 10$ & 17 & 1 & 0 & 1 & 0 & 0 \\
\hline
\end{tabular}

$0=$ No reactive cells; $1=<25 \%$ reactive cells; $2=26-50 \%$ reactive cells; $3=51-75 \%$ reactive cells; $4=76-99 \%$ reactive cells; $5=100 \%$ reactive cells.

Table 4 Number of cases of 19 cases of fibrocystic disease reacting, in different proportions, to various anticytokeratin antibodies

\begin{tabular}{lrrrrrr}
\hline \multicolumn{7}{c}{ Grade of reactivity } \\
\cline { 2 - 7 } Antibody & \multicolumn{7}{c}{1} & 2 & 3 & 4 & 5 \\
\cline { 2 - 7 } & \multicolumn{7}{c}{ Number of cases per grade } \\
\hline RCK105 & 0 & 0 & 1 & 1 & 5 & 12 \\
BA17 & 0 & 0 & 2 & 3 & 7 & 7 \\
M20 & 0 & 0 & 0 & 2 & 7 & 9 \\
RGE53 & 0 & 1 & 3 & 3 & 7 & 5 \\
Cam 5.2 & 0 & 1 & 1 & 0 & 0 & 17 \\
Anticytokeratin 14 & 15 & 2 & 0 & 0 & 0 & 0 \\
RCK102 & 0 & 1 & 0 & 0 & 7 & 11 \\
AE1 & 0 & 0 & 0 & 0 & 1 & 18 \\
AE3 & 0 & 0 & 0 & 1 & 3 & 15 \\
AE2 & 18 & 1 & 0 & 0 & 0 & 0 \\
LP34 & 0 & 0 & 0 & 0 & 3 & 16 \\
AE5 & 3 & 4 & 2 & 0 & 3 & 7 \\
AE8 & 19 & 0 & 0 & 0 & 0 & 0 \\
RSKE60 & 18 & 0 & 0 & 0 & 1 & 0 \\
6B10 & 19 & 0 & 0 & 0 & 0 & 0 \\
\hline D & &
\end{tabular}

$0=$ No reactive cells; $1=<25 \%$ reactive cells; $2=26-50 \%$ reactive cells; $3=51-75 \%$ reactive cells; $4=76-99 \%$ reactive cells; $5=100 \%$ reactive cells. 
cells in fibroadenomas reacting with both antibodies (cytokeratin $7 \mathrm{p}=0.0022$ and cytokeratin $19 \mathrm{p}=0.00312$ ). The proportions of tumour cells and luminal epithelial cells in fibrocystic disease which reacted with the antibody to cytokeratin $19(p=0.006)$ were

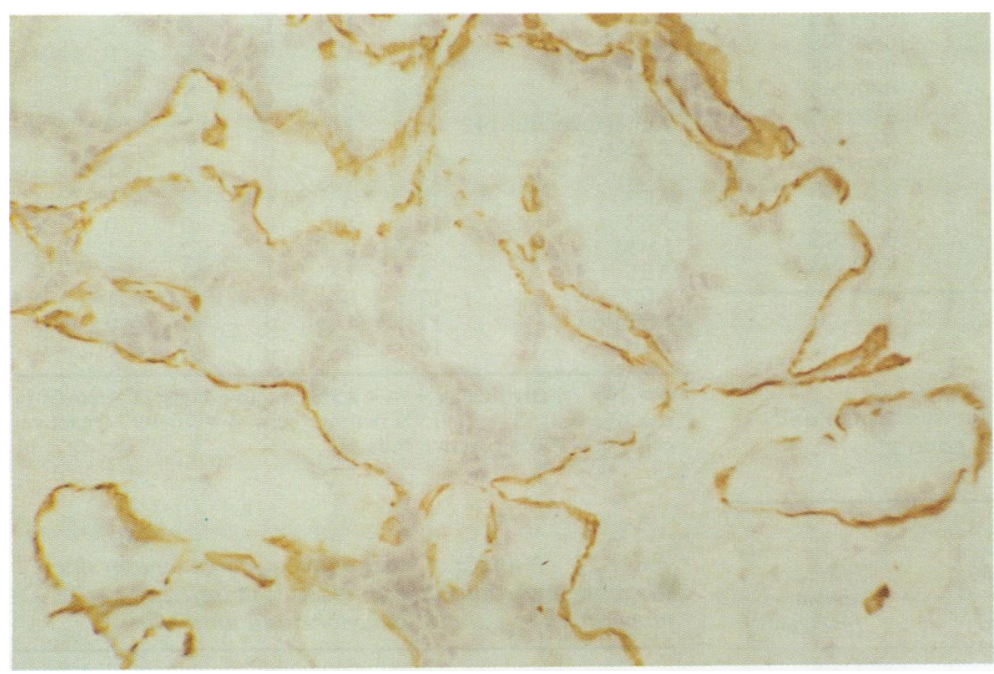

Figure 5 p positive reaction is present in the myoepithelial cells surrounding this focus of ductal carcinoma in situ with the specific antibody to cytokeratin 14 (frozen section $\times$ 240).

Table 5 Number of cases out of 64 infiltrating ductal carcinoma cases reacting, in different proportions, to various anticytokeratin antibodies

\begin{tabular}{lrrrrrr}
\hline \multicolumn{7}{c}{ Grade of reactivity } \\
\cline { 2 - 7 } Antibody & 0 & 1 & 2 & 3 & 4 & 5 \\
\cline { 2 - 6 } & \multicolumn{7}{c}{ Number of cases per grade } \\
\hline RCK105 & 7 & 4 & 1 & 8 & 12 & 35 \\
BA17 & 2 & 3 & 0 & 3 & 11 & 49 \\
M20 & 2 & 3 & 3 & 2 & 14 & 42 \\
RGE53 & 4 & 3 & 11 & 3 & 16 & 27 \\
Cam 5·2 & 1 & 2 & 3 & 2 & 6 & 54 \\
Anticytokeratin 14 & 61 & 2 & 0 & 0 & 0 & 1 \\
RCK102 & 4 & 2 & 1 & 3 & 9 & 45 \\
AE1 & 1 & 0 & 3 & 5 & 8 & 51 \\
AE3 & 7 & 0 & 2 & 6 & 11 & 40 \\
AE2 & 59 & 2 & 0 & 0 & 0 & 0 \\
LP34 & 1 & 2 & 4 & 4 & 9 & 48 \\
AE5 & 18 & 8 & 5 & 4 & 14 & 11 \\
AE8 & 60 & 1 & 1 & 1 & 0 & 0 \\
RSKE60 & 61 & 0 & 1 & 0 & 0 & 0 \\
6B10 & 55 & 5 & 0 & 0 & 0 & 3 \\
\hline
\end{tabular}

$0=$ No reactive cells; $1=<25 \%$ reactive cells; $2=26-50 \%$ reactive cells; $3=51-75 \%$ reactive cells; $4=76-99 \%$ reactive cells; $5=100 \%$ reactive cells.

Table 6 Summary of the reaction of antibodies to intermediate filament proteins in cells from benign and malignant conditions of the breast

\begin{tabular}{|c|c|c|c|c|c|c|}
\hline \multirow[b]{3}{*}{ Antibody } & \multicolumn{6}{|c|}{ The position of cells reacting to antibody } \\
\hline & \multicolumn{2}{|c|}{ Fibroadenoma } & \multicolumn{2}{|c|}{ Fibrocystic disease } & \multicolumn{2}{|c|}{ Adenocarcinoma } \\
\hline & Positive & Negative & Positive & Negative & Positive & Negative \\
\hline $\begin{array}{l}\text { RCK105 } \\
\text { BA17 } \\
\text { M20 } \\
\text { RGE53 } \\
\text { Cam 5·2 } \\
\text { Anticytokeratin } 14 \\
\text { RCK102 } \\
\text { AE1 } \\
\text { AE3 } \\
\text { AE2 } \\
\text { LP34 } \\
\text { AE5 } \\
\text { AE8 } \\
\text { RSKE60 } \\
\text { 6B10 }\end{array}$ & $\begin{array}{l}19^{\star} \\
18^{\star} \\
18 \dagger \\
17 \dagger \\
19 \dagger \\
1 \dagger \\
19 \dagger \\
19 \dagger \\
18 \dagger \\
2 \dagger \\
18 \dagger \\
13 \dagger \\
1 \dagger \\
1 \dagger \\
2 \dagger\end{array}$ & $\begin{array}{r}0 \\
1 \\
0 \\
0 \\
0 \\
17 \\
0 \\
0 \\
1 \\
17 \\
1 \\
5 \\
18 \\
17 \\
17\end{array}$ & $\begin{array}{l}19 \dagger \\
19 \star \\
18 \dagger \\
19 \dagger \\
19 \dagger \\
2 \dagger \\
19 \dagger \\
19 \dagger \\
19 \dagger \\
1 \dagger \\
19 \dagger \\
16 \dagger \\
0 \dagger \\
1 \dagger \\
0 \dagger\end{array}$ & $\begin{array}{r}0 \\
0 \\
0 \\
0 \\
0 \\
15 \\
0 \\
0 \\
0 \\
18 \\
0 \\
3 \\
19 \\
18 \\
19\end{array}$ & $\begin{array}{r}60 \\
66 \\
64 \\
60 \\
67 \\
3 \\
60 \\
67 \\
59 \\
2 \\
67 \\
42 \\
3 \\
1 \\
8\end{array}$ & $\begin{array}{r}7 \\
2 \\
2 \\
4 \\
1 \\
61 \\
4 \\
1 \\
7 \\
79 \\
59 \\
1 \\
18 \\
60 \\
61 \\
55\end{array}$ \\
\hline
\end{tabular}

${ }^{\star} \mathrm{p}<0.05 \mathrm{Mann}-$ Whitney $U$ test compared with infiltrating ductal carcinoma. t $\mathrm{p}>0.05$ Mann-Whitney $U$ test compared with infiltrating ductal carcinoma. significantly different, whilst the proportions reacting with the antibody to cytokeratin seven were not. No statistically significant differences were identified when these comparisons were made for the other antibodies studied.

Comparison of the proportion of tumour cells in different grades of infiltrating ductal carcinoma which reacted with the antibodies showed no evidence of a statistically significant difference (table 7).

Cytokeratin expression in tumour cells in lobular carcinomas (seven cases), mucinous carcinomas (three cases), and in the luminal epithelium of phyllodes tumours (three cases) reflected that noted for the more common breast lesions (table 8).

Cytokeratin expression in myoepithelial cells in the 19 fibroadenomas and 19 cases of fibrocystic disease was also studied (figs 1 and 2 ; tables 9 and 10). Although no case of ductal carcinoma in situ without invasion was examined, foci of ductal carcinoma in situ were identified in the breast tissue adjacent to invasive tumours in 22 cases (figs 3, 4, and 5). These results are presented in table 11 .

The reaction pattern identified in the myoepithelial cells was less predictable than that observed in the luminal epithelium and tumour cells. For example, the specific antibody to cytokeratin 14 , a protein which is usually widely distributed within the myoepithelium, did not detect these cells in 10 of the cases of benign breast disease and in situ carcinoma examined. Furthermore, each of the other antibodies to myoepithelial cytokeratins, RCK102 (detects cytokeratin 5), AE1 (detects cytokeratins 14 and 19), and AE3 (detects cytokeratins 5 and 7), reacted with the myoepithelium in less than half of the cases. These antibodies were less efficient than a specific antiactin antibody, which detected myoepithelial cells in all cases examined (figs 5 and 6 ).

Cytokeratin 14 was expressed in the myoepithelium in a greater proportion of cases of fibrocystic disease than in fibroadenoma cases $(p=0.008)$. There was no evidence of a statistically significant difference with any of the other antibodies examined (table 12).

\section{Discussion}

Luminal epithelial cells in the resting mammary gland express cytokeratins $7,8,16,18$, and 19 , whilst the myoepithelial cells express cytokeratins $5,7,14$, and $17 .{ }^{15}$ In addition, the expression of cytokeratins 18 and 19 by myoepithelial cells has been described by Wetzels $e t a l^{16}$ and Ferrero et $a l,{ }^{17}$ respectively.

As expected, the luminal epithelial cells in most cases of benign breast disease reacted with the specific antibodies to cytokeratin 7 , $8,18,19$, and to those antibodies which included these cytokeratins and cytokeratin 16 in their spectrum of reactivity (that is, RCK102, Cam 5.2, LP34, AE1, and AE3).

In a number of cases some epithelial cells did not express these cytokeratins, resulting in a heterogeneous reaction pattern in the luminal 
Table 7 Breast carcinomas reacting to anticytokeratin antibodies by tumour grade

\begin{tabular}{|c|c|c|c|c|c|}
\hline \multirow[b]{2}{*}{ Antibodies } & \multicolumn{5}{|c|}{ The proportion of cells reacting to antibody } \\
\hline & $\begin{array}{l}\text { Not } \\
\text { reacting }\end{array}$ & Grade I & Grade II & Grade III & $\begin{array}{l}\text { Kruskal-Wallis } \\
\text { test ( } p \text { value) }\end{array}$ \\
\hline RCK105 & 7 & 18 & 30 & 12 & $0.43 \mathrm{NS}$ \\
\hline BA17 & 2 & 22 & 32 & 12 & $0.61 \mathrm{NS}$ \\
\hline M20 & 2 & 20 & 31 & 13 & $0.54 \mathrm{NS}$ \\
\hline RGE53 & 4 & 21 & 29 & 10 & $0.26 \mathrm{NS}$ \\
\hline Cam $5 \cdot 2$ & 1 & 22 & 32 & 13 & $0.93 \mathrm{NS}$ \\
\hline Anticytokeratin 14 & 61 & 0 & 1 & 2 & $0.90 \mathrm{NS}$ \\
\hline RCK102 & 4 & 18 & 29 & 13 & $0.34 \mathrm{NS}$ \\
\hline AE1 & 1 & 23 & 31 & 13 & $0.56 \mathrm{NS}$ \\
\hline AE3 & 7 & 21 & 27 & 11 & $0.20 \mathrm{NS}$ \\
\hline $\mathrm{AE} 2$ & 59 & 0 & 2 & 0 & $0.30 \mathrm{NS}$ \\
\hline LP34 & 1 & 23 & 31 & 13 & $0.76 \mathrm{NS}$ \\
\hline AE5 & 18 & 12 & 18 & 12 & $0.07 \mathrm{NS}$ \\
\hline AE8 & 60 & 0 & 2 & 1 & $0.50 \mathrm{NS}$ \\
\hline RSKE60 & 61 & 0 & 1 & 0 & $0.50 \mathrm{NS}$ \\
\hline $6 \mathrm{~B} 10$ & 55 & 2 & 4 & 2 & $0.92 \mathrm{NS}$ \\
\hline
\end{tabular}

Table 8 Number of cases of lobular carcinoma, mucinous carcinoma and benign and malignant phyllodes tumours in which the epithelial cells reacted to a panel of anticytokeratin antibodies

\begin{tabular}{lllll}
\hline & \multicolumn{2}{l}{ Tumour type } & & \\
\cline { 2 - 5 } Antibody & $\begin{array}{l}\text { Lobular } \\
\text { carcinoma }\end{array}$ & $\begin{array}{l}\text { Mucinous } \\
\text { carcinoma }\end{array}$ & $\begin{array}{l}\text { Phyllodes } \\
\text { tumour } \\
\text { (benign) }\end{array}$ & $\begin{array}{l}\text { Phyllodes } \\
\text { tumour } \\
\text { (malignant) }\end{array}$ \\
\hline RCK105 & $5 / 7$ & $2 / 3$ & $2 / 2$ & $1 / 1$ \\
BA17 & $6 / 7$ & $3 / 3$ & $2 / 2$ & $1 / 1$ \\
M20 & $7 / 7$ & $2 / 2$ & $2 / 2$ & $1 / 1$ \\
RGE53 & $7 / 7$ & $2 / 2$ & $2 / 2$ & $1 / 1$ \\
Cam 5·2 & $7 / 7$ & $3 / 3$ & $2 / 2$ & $1 / 1$ \\
Anticytokeratin 14 & $0 / 7$ & $0 / 2$ & $1 / 2$ & $0 / 1$ \\
RCK102 & $5 / 6$ & $2 / 2$ & $2 / 2$ & $1 / 1$ \\
AE1 & $7 / 7$ & $3 / 3$ & $2 / 2$ & $1 / 1$ \\
AE3 & $7 / 7$ & $3 / 3$ & $2 / 2$ & $1 / 1$ \\
AE2 & $0 / 6$ & $0 / 2$ & $1 / 2$ & $0 / 1$ \\
LP34 & $7 / 7$ & $3 / 3$ & $2 / 2$ & $1 / 1$ \\
AE5 & $3 / 6$ & $1 / 2$ & $2 / 2$ & $1 / 1$ \\
AE8 & $0 / 6$ & $0 / 2$ & $0 / 2$ & $0 / 1$ \\
RSKE60 & $0 / 6$ & $0 / 2$ & $0 / 2$ & $0 / 1$ \\
6B10 & $0 / 6$ & $1 / 2$ & $0 / 2$ & $0 / 1$ \\
\hline
\end{tabular}

Table 9 Number of cases of fibroadenoma where the myoepithelial cells reacted, in different proportions, to various anticytokeratin antibodies

\begin{tabular}{lrrrrrr}
\hline \multicolumn{7}{c}{ Grade of reactivity } \\
\cline { 2 - 7 } & 0 & 1 & 2 & 3 & 4 & 5 \\
\cline { 2 - 7 } Antibody & \multicolumn{7}{c}{ Number of cases per grade } \\
\hline RCK105 & 15 & 0 & 1 & 0 & 0 & 3 \\
BA17 & 15 & 1 & 1 & 1 & 1 & 0 \\
M20 & 13 & 0 & 2 & 0 & 1 & 0 \\
RGE53 & 17 & 0 & 0 & 0 & 0 & 0 \\
Cam 5·2 & 12 & 2 & 0 & 0 & 0 & 5 \\
Anticytokeratin 14 & 4 & 5 & 5 & 0 & 1 & 3 \\
RCK102 & 10 & 2 & 0 & 3 & 0 & 4 \\
AE1 & 13 & 0 & 1 & 0 & 0 & 5 \\
AE3 & 11 & 0 & 1 & 2 & 1 & 3 \\
AE2 & 19 & 0 & 0 & 0 & 0 & 0 \\
LP34 & 9 & 2 & 2 & 0 & 0 & 6 \\
AE5 & 4 & 2 & 1 & 2 & 2 & 8 \\
AE8 & 15 & 0 & 0 & 1 & 1 & 0 \\
RSKE60 & 18 & 1 & 0 & 0 & 0 & 0 \\
6B10 & 19 & 0 & 0 & 0 & 0 & 0 \\
\hline 0 & & &
\end{tabular}

$0=$ No reactive cells; $1=<25 \%$ reactive cells; $2=26-50 \%$ reactive cells; $3=51-75 \%$ reactive cells; $4=76-99 \%$ reactive cells; $5=100 \%$ reactive cells.

epithelium. Similarly, other authors have described heterogeneous reactions with antibodies to cytokeratins $8,{ }^{18} 18,{ }^{18}{ }^{19}$ and $19 .{ }^{20} \mathrm{~A}$ number of carcinomas in the present study were entirely negative for one or more of these simple cytokeratins. Again, similar findings have been reported in the literature (cytokeratin 7 negative tumours ${ }^{71182122}$; cytokeratin 8 negative tumours ${ }^{18}$; cytokeratin 18 negative tumours ${ }^{161823}$; and cytokeratin 19 negative tumours $^{182024}$ ).
Table 10 Number of cases of fibrocystic disease where the myoepithelial cells reacted, in different proportions, to various anticytokeratin antibodies

\begin{tabular}{lrlllll}
\hline \multicolumn{7}{l}{ Grade of reactivity } \\
\cline { 2 - 7 } & 0 & 1 & 2 & 3 & 4 & 5 \\
\cline { 2 - 7 } Antibody & \multicolumn{7}{l}{ Number of cases per grade } \\
\hline RCK105 & 17 & 0 & 1 & 0 & 0 & 0 \\
BA17 & 15 & 1 & 1 & 0 & 0 & 1 \\
M20 & 15 & 1 & 0 & 0 & 0 & 0 \\
RGE53 & 19 & 0 & 0 & 0 & 0 & 0 \\
Cam 5·2 & 12 & 2 & 0 & 1 & 0 & 3 \\
Anticytokeratin 14 & 1 & 1 & 2 & 1 & 2 & 8 \\
RCK102 & 14 & 0 & 0 & 0 & 1 & 3 \\
AE1 & 12 & 0 & 1 & 2 & 1 & 2 \\
AE3 & 10 & 3 & 1 & 0 & 0 & 4 \\
AE2 & 19 & 0 & 0 & 0 & 0 & 0 \\
LP34 & 8 & 0 & 1 & 2 & 1 & 6 \\
AE5 & 5 & 1 & 1 & 0 & 5 & 6 \\
AE8 & 17 & 0 & 0 & 0 & 1 & 0 \\
RSKE60 & 17 & 1 & 0 & 0 & 0 & 0 \\
6B10 & 19 & 0 & 0 & 0 & 0 & 0 \\
\hline
\end{tabular}

$0=$ No reactive cells; $1=<25 \%$ reactive cells; $2=26-50 \%$ reactive cells; $3=51-75 \%$ reactive cells; $4=76-99 \%$ reactive cells; $5=100 \%$ reactive cells.

Table 11 Number of cases of ductal carcinoma in situ where the myoepithelial cells reacted, in different proportions, to various anticytokeratin antibodies

\begin{tabular}{lrllllr}
\hline \multicolumn{7}{c}{ Grade of reactivity } \\
\cline { 2 - 7 } & 0 & 1 & 2 & 3 & 4 & 5 \\
\cline { 2 - 7 } Antibody & \multicolumn{7}{c}{ Number of cases per grade } \\
\hline RCK105 & 15 & 3 & 0 & 1 & 0 & 1 \\
BA17 & 17 & 2 & 0 & 1 & 0 & 2 \\
M20 & 22 & 0 & 0 & 0 & 0 & 0 \\
RGE53 & 22 & 0 & 0 & 0 & 0 & 0 \\
Cam 5·2 & 18 & 0 & 0 & 0 & 1 & 2 \\
Anticytokeratin 14 & 5 & 1 & 2 & 2 & 2 & 6 \\
RCK102 & 14 & 0 & 0 & 0 & 3 & 1 \\
AE1 & 11 & 0 & 2 & 0 & 2 & 7 \\
AE3 & 15 & 0 & 0 & 0 & 1 & 4 \\
AE2 & 22 & 0 & 0 & 0 & 0 & 0 \\
LP34 & 6 & 0 & 1 & 1 & 2 & 12 \\
AE5 & 10 & 0 & 1 & 0 & 3 & 4 \\
AE8 & 15 & 0 & 0 & 0 & 3 & 0 \\
RSKE60 & 19 & 0 & 0 & 0 & 0 & 0 \\
6B10 & 22 & 0 & 0 & 0 & 0 & 0 \\
\hline
\end{tabular}

$0=$ No reactive cells; $1=<25 \%$ reactive cells; $2=26-50 \%$ reactive cells; $3=51-75 \%$ reactive cells; $4=76-99 \%$ reactive cells; $5=100 \%$ reactive cells.

The complete absence of simple cytokeratins in breast ductal and lobular carcinomas may be because these tumours may have arisen in those luminal epithelial cells of the terminal duct lobular units which did not express these proteins. ${ }^{20}$ That this represents a genuine absence of the cytokeratin, rather than masking of an epitopic site or the effect of fixation, is supported by studies in which several antibodies were used, reacting with more than one epitopic site on a given cytokeratin, ${ }^{722}$ and by the use of frozen sections, in which immunoreactivity is optimally preserved, as in the current series.

As cases in which all of the epithelial cells were negative for cytokeratins 7,8 , and 18 were limited to carcinomas, the use of these antibodies may provide a convenient means for distinguishing benign from malignant breast disease in some borderline cases. The cancer cells in two adenocarcinomas were completely negative for cytokeratin 19 and a statistically significant difference was found when cytokeratin 19 expression was compared in ductal carcinomas and benign breast 


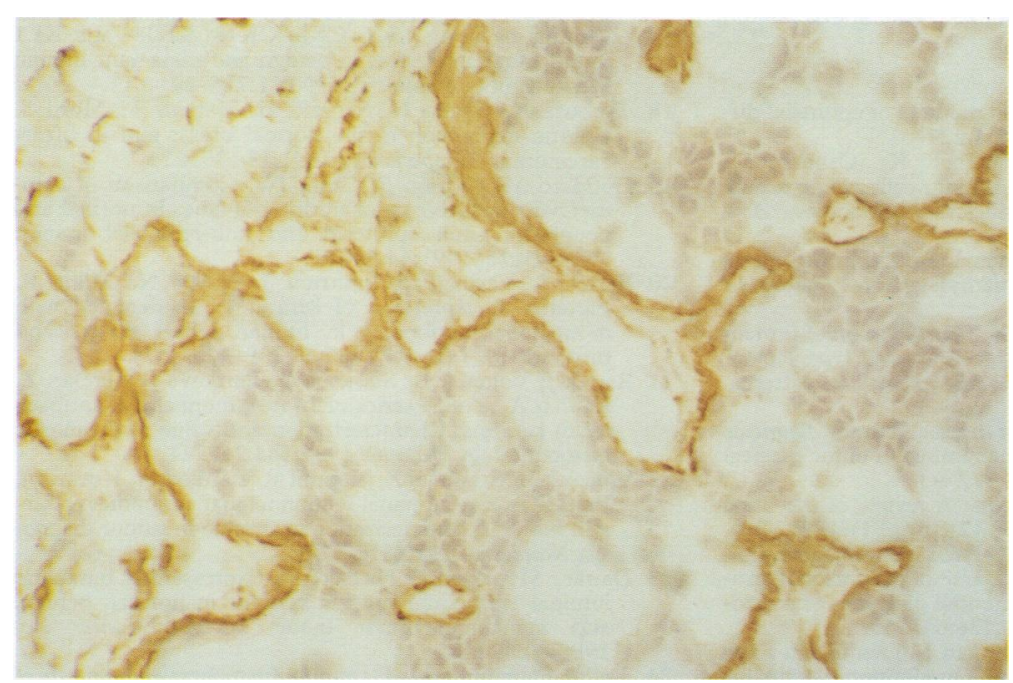

Figure 6 The myoepithelial cells also reacted to an antibody to actin. This antibody also reacts with the blood vessels in the adjacent stroma (frozen section $\times 240$ ).

disease. However, as the luminal epithelium in one case of fibroadenoma was entirely nonreactive for this antibody, its value as a diagnostic discriminator is limited. Findings similar to those described in cases of benign breast disease were identified in the luminal epithelium in the two phyllodes tumours.

Three cytokeratin 14 positive tumours were observed in this series and in one case all of the tumour cells were positive. Gustersen et $a l^{25}$ and Wetzels et $a l^{16}$ identified basement membrane components in the tumour cells in a proportion of such tumours, suggesting that they arose from the myoepithelial layer of the breast. However, cytokeratin 14 expression in the absence of other markers of myoepithelial differentiation has also been described in breast tumours. ${ }^{26}$ Occasional luminal cells in the terminal duct lobular unit, which react with antibodies to cytokeratin 14, have been described by Nagle et al ${ }^{27}$ and these cells may be the origin of some cytokeratin 14 positive tumours. Cytokeratin 14 expression may also represent a change in the cytokeratin profile with the acquisition of malignant char-

Table 12 Summary of the reaction of antibodies to intermediate filament proteins to myoepithelial cells from benign and malignant conditions of the breast

\begin{tabular}{|c|c|c|c|c|c|c|}
\hline \multirow[b]{3}{*}{ Antibody } & \multicolumn{6}{|c|}{ The proportion of cells reacting to antibody } \\
\hline & \multicolumn{2}{|c|}{ Fibroadenoma } & \multicolumn{2}{|c|}{ Fibrocystic disease } & \multicolumn{2}{|c|}{$\begin{array}{l}\text { Ductal carcinoma } \\
\text { in situ }\end{array}$} \\
\hline & Positive & Negative & Positive & Negative & Positive & Negative \\
\hline RCK105 & 4 & 15 & 1 & 17 & 5 & 15 \\
\hline BA17 & 4 & 15 & 3 & 15 & 5 & 17 \\
\hline M20 & 3 & 13 & 1 & 15 & 0 & 22 \\
\hline RGE53 & 0 & 17 & 0 & 19 & 0 & 22 \\
\hline Cam $5 \cdot 2$ & 7 & 12 & 6 & 12 & 3 & 18 \\
\hline Anticytokeratin 14 & 14 & 4 & $14^{\star}$ & 1 & 13 & 5 \\
\hline RCK 102 & 9 & 10 & 4 & 14 & 4 & 14 \\
\hline $\mathrm{AE} 1$ & 6 & 13 & 6 & 12 & 11 & 11 \\
\hline AE3 & 7 & 11 & 8 & 10 & 5 & 15 \\
\hline AE2 & 0 & 19 & 0 & 19 & 0 & 22 \\
\hline LP34 & 10 & 9 & 10 & 18 & 16 & 6 \\
\hline AE5 & 15 & 4 & 13 & 5 & 8 & 10 \\
\hline AE8 & 2 & 15 & 1 & 17 & 3 & 15 \\
\hline RSKE60 & 1 & 18 & 1 & 17 & 0 & 19 \\
\hline $6 \mathrm{~B} 10$ & 0 & 19 & 0 & 19 & 0 & 22 \\
\hline
\end{tabular}

${ }^{\star} \mathrm{p}<0.05$ Mann-Whitney $U$ test compared with fibroadenoma. acteristics. The acquisition of cytokeratin 14 expression has been described in tumours of the urinary bladder. ${ }^{8}$ The finding that both simple cytokeratins and cytokeratin 14 were co-expressed in three tumours in the present study and that none of them reacted to a specific antibody to actin would lend support to either of these latter hypotheses.

Reactions with the antibodies AE2 (cytokeratins 1, 2, 10, and 11), AE5 (cytokeratin 3), AE8 (cytokeratin 13), RSKE60 (cytokeratin 10), and 6B10 (cytokeratin 4) were identified in the luminal epithelium in occasional cases of benign breast disease and of invasive cancers. Of these, only cytokeratin 13 has been previously reported within breast epithelium. ${ }^{16}$ Statistically significant differences in cytokeratin expression with increasing tumour grade did not occur with any of the antibodies studied. Therefore, the value of the cytokeratin profile in assessing tumour grade and prognosis in breast carcinoma appears to be limited.

The detection in myoepithelium of cytokeratins $7,18,19$, and 14 with specific antibodies to these proteins reflects the results of previous studies. ${ }^{15-182326-30}$ The reaction with myoepithelium of a number of antibodies which detect more than one cytokeratin reflects their ability to detect specific cytokeratins which are known to be expressed by these cells (Cam 5.2, cytokeratins 18 and 19; RCK102, cytokeratin 5; AE1, cytokeratin 14; AE3, cytokeratin 5; LP34, cytokeratin 18). Of these, cytokeratin 14 has been most extensively studied. Cytokeratin 14 expression has been localised to the myoepithelial cells in the normal breast, in cases of benign breast disease $^{16182326-30}$ and in surrounding foci of in situ carcinoma. ${ }^{162729}$ In this study and that of Dairkee et $\mathrm{al}^{26}$ a reaction to cytokeratin 14 in the myoepithelial cells was absent in some cases of benign disease. As in this series, Gottlieb et al $^{30}$ found that a monoclonal antibody to cytokeratin 14 was a less sensitive means of detecting myoepithelial cells than the use of antiactin antibodies.

This is the first study in which cytokeratins $1,2,10$, or 11 (AE2), cytokeratin 3 (AE5), cytokeratin 10 (RSKE60), and cytokeratin 4 (6B10) have been immunolocalised in myoepithelial cells. In contrast to our findings Nagle et $a l^{27}$ were unable to detect cytokeratin 13 in these cells using an alternative antibody (2D7). Neither we nor TaylorPapadimitriou ${ }^{24}$ or Guelstein et al ${ }^{31}$ were able to detect cytokeratin 8 in myoepithelial cells.

In conclusion, cytokeratins 7,8 , and 18 were invariably expressed in benign breast disease and when absent, were reliable indicators of malignancy. Cytokeratin expression showed no statistically significant association with breast tumours of differing histological grade, but was of some value in outlining the myoepithelial layers surrounding foci of in situ carcinoma, enabling these lesions to be differentiated from invasive carcinomas.

Supported by the Ulster Cancer Foundation and The Royal Group of Hospitals Trust. We are grateful for the photographic expertise provided by $\mathrm{Mr}$ R Creighton and to Mrs E 
McNamee who typed the paper. We also thank Dr C Patterson for statistical advice.

1 Fuchs E. Keratins as biochemical markers of epithelial differentiation. Trends Genet 1988;4:227-81.

2 Domagala W, Lubinski J, Weber $\mathrm{K}$, Osborn $M$. Intermediate filament typing of tumor cells in fine needle aspirates by means of monoclonal antibodies. Acta Cytologica 1986;30:214-24.

3 Lehto VP, Miettinen M, Virtanen I. Antibodies to intermediate filaments in surgic

4 Moll $R$ Schiller DL Franke WW. Identification of protein IT of the intestinal cytoskeleton as a novel type 1 cytokeratin with unusual properties and expression patterns. keratin with unusual properties

5 Osborn M, Weber K. Biology of disease. Tumor diagnosis by intermediate filament typing: a novel tool for surgical by intermediate filament typing: a novel

6 Nagle RB. Intermediate Filaments: A review of the basic biology. Am f Surg Pathol 1988;12(Suppl 1):4-16.

7 Ramaekers F, van Niekerk C, Poels L, Schaafsma E, Huijsmans A, Robben $\mathrm{H}$, et al. Use of monoclonal antibodies to keratin 7 in the differential diagnosis of adenocarcinomas. Am F Pathol 1990;136:641-55.

8 Schaafsma HE, Ramaekers FCS, van Muijen GNP, Lane EB, Leigh IM, Robben H, et al. Distribution of cytokeratin polypeptides in human transitional cell carcinomas, with special emphasis on changing expression pattern with special emphasis on changing expression pattern 329-43.

9 Smedts F, Ramaekers F, Robben H, Pruszczynski M, van Muijen G, Lane B, et al. Changing patterns of keratin expression during progression of cervical intraepithelial neoplasia. Am $\mathcal{F}$ Pathol 1990;136:657-68.

10 Broers JLV, Ramaekers FCS, Rot MK, Oostendorp T, Huysmans A, van Muijen GNP, et al. Cytokeratins in different types of human lung cancer as monitored by chain-specific monoclonal antibodies. Cancer Res 1988 48:322 $1-9$.

11 Battifora $\mathrm{H}$. Clinical applications of the immunohistochemistry of filamentous proteins. Am $f$ Surg Pathol 1988;12(Suppl 1):24-42.

12 Corson JM. Keratin protein immunohistochemistry in surgical pathology practice. Pathol Annu 1986;21:47-81.

13 Bloom HJG, Richardson WW. Histological grading and prognosis in breast cancer. A study of 1409 cases of which 359 have been followed for fifteen years. $\mathrm{Br} \mathcal{F}$ Cancer 1957;11:359-77.

14 Elston CW, Gresham GA, Rao GS, Zebro T, Haybittle JL Houghton J, et al. (On behalf of cancer research campaign working party). The cancer research campaign (King's/Cambridge) trial for early breast cancer: Clinicopathological aspects. $\mathrm{Br} \mathcal{F}$ Cancer 1982; 45:655-69.

15 Mork C, van Deurs B, Petersen OW. Regulation of vimentin expression in cultured human mammary epithelial cells. Differentiation 1990;43:146-56.

16 Wetzels RHW, Kuijpers HJH, Lane EB, Leigh IM, Troyanovsky SM, Holland R, et al. Basal cell-specific Troyanovsky SM, Holland R, et al. Basal cell-specific and hyperproliferation-related keratins

17 Ferrero M, Spyratos F, Le Doussal V, Desplaces A,
Rouesse J. Flow cytometric analysis of DNA content and keratins by using CK7, CK8, CK18, CK19, and KL1 monoclonal antibodies in benign and malignant human breast tumors. Cytometry 1990;11:716-24.

18 Tsubura A, Okada H, Senzaki H, Hatano T, Morii S. Keratin expression in the normal breast and in breast carcinoma. Histopathology 1991;18:517-22.

19 Goddard MJ, Wilson B, Grant JW. Comparison of commercially available cytokeratin antibodies in normal and neoplastic adult epithelial and non-epithelial tissues. f Clin Pathol 1991;44:660-3.

20 Bartek J, Taylor-Papadimitriou J, Miller N, Millis R. Patterns of expression of keratin 19 as detected with monoclonal antibodies in human breast tissues and tumours. Int $\mathcal{f}$ Cancer 1985;36:299-306.

21 Bartek J, Vojtesek B, Staskova Z, Bartkova J, Kerekes Z, Rejthar A, et al. A series of 14 new monoclonal antibodies to keratins: Characterization and value in diagnostic histopathology. F Pathol 1991;164:215-24.

22 Vojtesek B, Staskova Z, Nenutil R, Bartkova J, Kovarik J, Rejthar A, et al. A panel of monoclonal antibodies to keratin No. 7: Characterization and value in tumor diagnosis. Neoplasma 1990;37:333-42.

23 Dairkee SH, Puett L, Hackett AJ. Expression of basal and luminal epithelium-specific keratins in normal, benign, and malignant breast tissue. I Natl Cancer Inst 1988;80:691-5.

24 Taylor-Papadimitriou J. Immunohistochemical analysis of benign and malignant breast tumours. Pathol Biol 1990; 38:778.

25 Gusterson BA, Warburton MJ, Mitchell D, Ellison M, Neville AM, Rudland PS. Distribution of myoepithelial cells and basement membrane proteins in the normal cells and basement membrane proteins in the normal breast and in benign and
Cancer Res 1982;42:4763-70.

26 Dairkee SH, Ljung BM, Smith H, Hackett A. Immunolocalization of a human basal epithelium specific keratin in benign and malignant breast disease. Breast Cancer Res Treat 1987;10:11-20.

27 Nagle RB, Bocker W, Davis JR, Heid HW, Kaufmann M, Lucas DO, et al. Characterization of breast carcinomas by two monoclonal antibodies distinguishing myoepithelial from luminal epithelial cells. 7 Histochem Cytochem 1986;34:869-81.

28 Gould VE, Koukoulis GK, Jansson DS, Nagle RB, Franke WW, Moll R. Coexpression patterns of vimentin and glial filament protein with cytokeratins in the normal, glial filament protein with cytokeratins in the normal, hyperplastic and

29 Wetzels RHW, Holland R, van Haelst UJGM, Lane EB, Leigh IM, Ramaekers FCS. Detection of basement membrane components and basal cell keratin 14 in noninvasive and invasive carcinomas of the breast. $A m \mathcal{F}$ Pathol 1989;134:571-9.

30 Gottlieb C, Raju U, Greenawald KA. Myoepithelial cells in the differential diagnosis of complex benign and malignant breast lesions: an immunohistochemical study. Mod Pathol 1990;3:135-40.

31 Guelstein VI, Tchrypysheva TA, Ermilova VD, Litvinova LV, Troyanovsky SM, Bannikov GA. Monoclonal antibody mapping of keratins 8 and 17 and of vimentin in body mapping of keratins 8 and 17 and of vimentin in
normal human mammary gland, benign tumours, dysplasias and breast cancer. Int $\mathcal{F}$ Cancer 1988;42:147-53. 